\title{
Information Platforms and the Global Network Economy
}

\author{
Elmira Gojayeva ${ }^{1}$, Shahla Huseynova ${ }^{2, *}$, Saida Babayeva $^{2}$, Ulker Sadigova ${ }^{1}$, and Reyhan \\ Azizova $^{2}$ \\ ${ }^{1}$ Azerbaijan Tourism and Management University, The Department of Management, K.Rahimov str. \\ 822/23, AZ1072 Baku, Azerbaijan \\ ${ }^{2}$ Azerbaijan State University of Economics, Department of Digital Economy and ICT, Istiglaliyyat 6, \\ AZ1001 Baku, Azerbaijan
}

\begin{abstract}
.
Research background: The research investigates the formation of the intellectual elite; a radical modernization of the education system is necessary with the use of IT technologies and the introduction of innovations created on the basis of scientific achievements. The development of human capital is crucial for the transition from a traditional economy to a knowledge economy.

Purpose of the article: The aim of the article is to show how human capital plays a very important role in the country's economy, the knowledge that is concentrated in it, allows you to develop a knowledge economy - a type of economy based on the use of this capital. The formation of human capital is associated with investment and high-quality modern education. Modernization of higher education is closely related to the use of information and communication technologies and the introduction of innovations. Distance education can be the beginning of a new stage of higher education.

Methods: The method of observation, concretization and abstraction, comparative analysis, abstract-logical, economic-statistical, theoretical and practical assessment were used in the study of various aspects of the research.

Findings \& Value added: Large-scale reforms carried out in the state have led to an improvement in the standard of living of our society, and it has become possible to improve social infrastructure: housing, its construction, social and cultural facilities, health care systems, education, sports and fitness facilities, etc.
\end{abstract}

Keywords: education; information and communication technologies; human capital; modernization; network economy.

JEL Classification: $A 22 ; I 21 ; J 24$

\footnotetext{
*Corresponding author: Shahla Huseynova@unec.edu.az
} 


\section{Introduction}

Foreign experts, having studied the dynamics of development of modern societies, conclude that human capital (a high level of knowledge, information component) is a priority resource for the development of the 21st century, giving an advantage of some states over others. Purposeful development of human capital will lead to a positive and stable economic recovery of countries. In this regard, the main task of the country's education system should be the creation and development of such human capital, through which it can be successfully integrated into the global economic system and become a competitive state. This approach should become the main task of the educational policy of each state. State spending on education has a high economic profitability for society, since despite the initial large investments, they will certainly become economically profitable due to the creation of highly professional human capital. Currently, modern Azerbaijan is undergoing high socioeconomic progress. Large-scale reforms carried out in the state have led to an improvement in the standard of living of our society, there is an opportunity to improve social infrastructure: housing, its construction, social and cultural facilities, health care systems, education, sports and recreation facilities; passenger transport and communications, the system of social protection of the population, etc. All these reforms and transformations will become impossible if the country does not implement the "State Strategy for the Development of Education", the task of which is to ensure the development of human capital as the main component of creating a "knowledge economy" and modernization of the country. The number of dengue cases is often observed to increase at the beginning of the year due to the rainy season and high temperatures and peak between March and April. Meanwhile, the peak of the COVID-19 outbreak in Brazil is forecast to occur between late April and early May, when respiratory diseases are most commonly found. This temporal coincidence implies that the two outbreaks may happen at the same time. This would cause great damage to population and therefore require intensive attention from both the private health system and the public Unified Health System (SUS) [1].

\section{Methods}

In the 21 st century, a number of problems arose in the world higher education system due to the difference in the level of development of culture and science. And a natural way out of this situation is the need to modernize higher education, within the framework of which the elite is trained (political, economic, cultural, etc.). The basis of the state's intellectual potential is staff with a high level of professional education. It is education that plays a special role in creating human capital - the formation of an intellectual elite that can take full advantage of the opportunities provided by information technologies.

The 2019-nCoV infection was of clustering onset, is more likely to affect older males with comorbidities, and can result in severe and even fatal respiratory diseases such as acute respiratory distress syndrome. In general, characteristics of patients who died were in line with the MuLBSTA score, an early warning model for predicting mortality in viral pneumonia. Further investigation is needed to explore the applicability of the MuLBSTA score in predicting the risk of mortality in 2019-nCoV infection [2].

It is no secret that the intellectual potential of the country is made up of professional personnel with a high level of education. And this will help create highly professional human capital in Azerbaijan. This strategy was included in the "Development Concept" Azerbaijan 2020: a look into the future "approved by the Decree of the President of the Republic of Azerbaijan dated December 29, 2012. Information and communication technologies are one of the main directions of such development. Failing to consider COVID-19 because of a positive dengue rapid test result has serious implications not only 
for the patient but also for public health. Our cases highlight the importance of recognising false-positive dengue serology results (with different commercially available assays) in patients with COVID-19. We emphasise the urgent need for rapid, sensitive, and accessible diagnostic tests for SARS-CoV-2, which need to be highly accurate to protect public health [3]. Information and communication technologies is a new economic sector with high growth rates, playing the role of a modern and multifunctional infrastructure, as well as a lever for all-round socio-economic progress. Today, information and communication technologies are perceived as a favourable means for ensuring the constant and sustainable development of the republic, strengthening its intellectual and human potential, developing business, combating negative phenomena and developing transparency and democracy in society [4]. Information and communication technologies, which have created new values in public administration, education, healthcare, business, banking and other areas, have become an important component of socio-economic relations. Information and communication technologies provide society with such opportunities as: freedom of communication on the Internet, the development of Internet media, domestic and foreign social networks. The virus causing coronavirus disease 2019 (COVID-19) has now become pandemic. How has it managed to spread from China to all around the world within 3 to 4 months? Li et al. used multiple sources to infer the proportion of early infections that went undetected and their contribution to virus spread. The researchers combined data from Tencent, one of the world's largest social media and technology companies, with a networked dynamic metapopulation model and Bayesian inference to analyze early spread within China. They estimate that $\sim 86 \%$ of cases were undocumented before travel restrictions were put in place. Before travel restriction and personal isolation were implemented, the transmission rate of undocumented infections was a little more than half that of the known cases. However, because of their greater numbers, undocumented infections were the source for $\sim 80 \%$ of the documented cases. Immediately after travel restrictions were imposed, $\sim 65 \%$ of cases were documented. These findings help to explain the lightning-fast spread of this virus around the world [5].

In the XXI century, the improvement of computer technology and the rapid growth of the Internet raised the development of the information society to a high level. In this society, the main resource is information, the possession of which makes it possible to intensively implement and constructively build any type of activity. The basis of the information society is a progressive education system based on the use of modern methods and information technologies. The introduction of a personal computer into the field of education has become a new stage not only in the transformation of traditional methods and technologies of teaching, but also in the entire education sector as a whole. The processes of globalization, the penetration of modern information and communication technologies into all spheres of society, the transition to an information society lead to the need to change traditional approaches to teaching and learning, the introduction of effective methods for the formation and transfer of knowledge, and the process of obtaining new knowledge should be continuous.

\section{Results and Discussions}

Therefore, if we consider the digital economy as an evolutionary stage in the development of the economy, then we can highlight the relationship between the process of its formation and the evolution of the main sources of wealth (Tab. 1). Conventionally, the stages of the formation of the digital economy can be formulated as follows: 
Table 1. Evolution of socio-economic relations

\begin{tabular}{|c|c|c|c|}
\hline & $\begin{array}{l}\text { AGRARIAN } \\
\text { ECONOMY }\end{array}$ & $\begin{array}{l}\text { INDUSTRIAL } \\
\text { ECONOMY }\end{array}$ & $\begin{array}{c}\text { ECONOMY } \\
\text { KNOWLEDGE }\end{array}$ \\
\hline $\begin{array}{l}\text { The basis of } \\
\text { social } \\
\text { economic } \\
\text { relations }\end{array}$ & $\begin{array}{l}\text { Traditional society; } \\
\text { Communities, estates, } \\
\text { cities. }\end{array}$ & $\begin{array}{l}\text { Society of Art Nouveau; } \\
\text { Free labor market. }\end{array}$ & $\begin{array}{l}\text { Post-industrial society; } \\
\text { Communication based on } \\
\text { information technology. }\end{array}$ \\
\hline $\begin{array}{l}\text { The main } \\
\text { source of wealth }\end{array}$ & $\begin{array}{l}\text { Land, the origin of } \\
\text { handicraft; Agricultural } \\
\text { production (the bulk of } \\
\text { the population is } \\
\text { employed in the primary } \\
\text { sector - agriculture). }\end{array}$ & $\begin{array}{l}\text { Resources (on the surface } \\
\text { and in the bowels of the } \\
\text { earth; } \\
\text { Industry (the bulk of the } \\
\text { population is employed in } \\
\text { secondary sector - } \\
\text { industrial production). }\end{array}$ & $\begin{array}{l}\text { Scalable knowledge } \\
\text { (shaping global thinking); } \\
\text { Knowledge economy (the } \\
\text { bulk of the population is } \\
\text { employed in the tertiary } \\
\text { sector - the service } \\
\text { sector). }\end{array}$ \\
\hline $\begin{array}{l}\text { An important } \\
\text { economic factor }\end{array}$ & Earth & Capital & Knowledge \\
\hline
\end{tabular}

1. The era of logistics. The main way to generate income was to deliver the goods to the buyer. It was this circumstance that forced merchants (entrepreneurs) to organize risky expeditions to geographically distant countries, which, incidentally, led to the Great Geographical Discoveries. Transportation costs in the pricing structure during that period amounted to more than $95 \%$. The heroes of the era can be considered Giacomo Medici, Fernand Magellan, J.P. Morgan.

2. The era of retail. This era began with the development of mechanized transport. The main concept of income generation was to bring the product directly to the end consumer. Trading networks became the main place of income generation. The most prominent representatives of the era are Ingvar Kampard, Sam Walton, Richard Branson.

3. The era of information. The advent of the Internet has brought the customer even closer to business. Both purchasing behaviour and the methods of studying it have changed. Manufacturers received new tools and learned to re-examine consumer behavior. Targeting on the Internet allows you to offer a specific buyer the product he needs at a given time. Examples of business success in this era were demonstrated by Pierre Omidyar, Jeff Bezos and Jack Ma.

4. The era of knowledge. Recent economic history is being written by companies led by Larry Page, Mark Zuckerberg and Arkady Volozh. Their companies, collecting information on the network and studying it, create a knowledge base about consumer behavior to form his digital profile in order to manage it.

Modern rates of changes in the economy are fundamentally changing the approaches to managing economic processes. The digital transformation of business entities and relevant authorities, as socio-economic systems, together provides the basis for the formation of a digital economy. As noted earlier, this accelerates the processes of serviceization of economic activities, which we consider necessary to be considered in connection with digital transformation. As indicated in previous research materials, there are different views of both understanding the essence of the concept of "digital transformation" and the definition of transformational effects. In our opinion, the digital transformation format, its speed and effects cannot be the same for all economic agents, however, a unified methodology and a certain set of universal recommendations for transforming socioeconomic systems through digital transformation from the scientific basis for the success and effectiveness of the transition to digital economy, including considering the growing trend of digitalization. "Methodology is the logical organization of human activity, which consists in defining the goal and subject of research, approaches and guidelines in its conduct, the choice of means and methods that determine the best result. Any human 
activity is characterized by methodology. But in research, methodology plays a critical role in success. " In this regard, the methodology of digital transformation of socio-economic systems is nothing more than the beginning of the process of learning the essence of digital transformation, presented in the form of a system of theoretical postulates and limitations, considered in a complex of specific methods and techniques of scientific knowledge, both of individual objects and of the socio-economic system in the whole. Thus, a new reality has developed in the world, which prompts the governments of all countries to pursue a policy of a systemic digital economy through digital transformation: to improve the relevant branches of national legislation, to develop and implement large-scale government strategies, projects, programs. Of course, the two main priorities are almost always ensuring the international competitive advantages of the country (region, interstate association) related to the development of the digital economy and optimizing internal development. Moreover, the effectiveness of their application strongly depends on the cultural and civilizational environment, region or even country in which this or that strategy is being implemented. In other words, there are no universal models of state governance through digital transformation mechanisms; a lot depends on the institutional environment. In carrying out further research and development, we will adhere to the point of view and understanding of digital platforms as unique digital technologies, on the basis of which the interaction of economic entities, service in nature, is built. Further, it seems appropriate to consider the concept of a "service integrator" as a key subject of a digital platform that regulates and directs the flows of related services, as well as the transformation of its role in the digital economy.

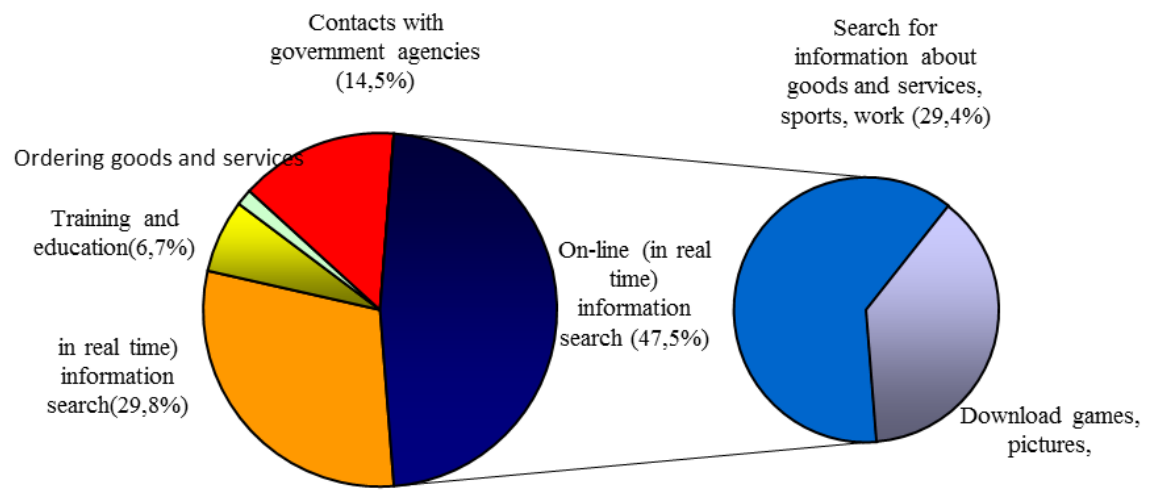

Fig. 1. The structure of the goals of Internet users, in percent
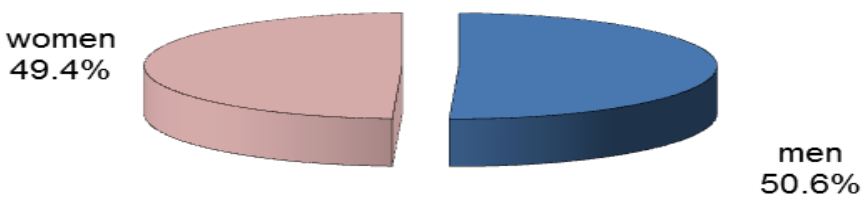

Fig. 2. Distribution of employees using the Internet, as a percentage of the final (Discussion Output)

By mid-March, not a single European country remained unaffected by the virus, and many countries simply closed their borders and introduced massive quarantines - for the first time in the history of modern mankind. On March 11, 2020, the World Health 
Organization declared the coronavirus infection COVID-19, which is caused by the pathogen SARS-CoV-2, a pandemic [6].

Table 2. Coronavirus statistics by country

\begin{tabular}{|c|c|c|c|c|c|c|}
\hline \multirow{2}{*}{\begin{tabular}{|l|l} 
Countries \\
Dates
\end{tabular}} & \multicolumn{2}{|c|}{ Infected } & \multicolumn{2}{|c|}{ Recovered } & \multicolumn{2}{|c|}{ Deceased } \\
\hline & 11.03 .2020 & 27.04 .2020 & 11.03 .2020 & 27.04 .2020 & 11.03 .2020 & 27.04 .2020 \\
\hline World & 119,239 & $3,058,186$ & 66,335 & 919,727 & 4,290 & 211,147 \\
\hline China & 80,778 & 82,830 & 61,475 & 77,474 & 3,158 & 4,633 \\
\hline Italy & 10,149 & 199,414 & 1,004 & 66,624 & 631 & 26,977 \\
\hline Iran & 8,042 & 91,472 & 2,731 & 70,933 & 291 & 5,806 \\
\hline $\begin{array}{l}\text { South } \\
\text { Korea }\end{array}$ & 7,755 & 10,738 & 288 & 8,764 & 60 & 243 \\
\hline France & 1,784 & 165,842 & 12 & 45,513 & 30 & 23,293 \\
\hline Germany & 1,565 & 158,434 & 18 & 114,500 & 2 & 6,061 \\
\hline Spain & 1,695 & 229,422 & 135 & 120,832 & 36 & 23,521 \\
\hline USA & 978 & $1,007,162$ & 9 & 137,720 & 30 & 56,595 \\
\hline Japon & 581 & 13,441 & 59 & 1,809 & 10 & 372 \\
\hline Sweden & 326 & 18,926 & 0 & 1,005 & 0 & 2,274 \\
\hline Belgium & 267 & 46,687 & 1 & 10,878 & 0 & 10,878 \\
\hline Singapore & 166 & 14,423 & 93 & 1,095 & 0 & 14 \\
\hline Australia & 101 & 6,720 & 22 & 5,586 & 3 & 83 \\
\hline Canada & 72 & 48,458 & 8 & 18,215 & 1 & 2,704 \\
\hline Brazil & 34 & 66,501 & 0 & 31,142 & 0 & 4,543 \\
\hline Russia & 20 & 87,147 & 3 & 7,346 & 0 & 794 \\
\hline $\begin{array}{l}\text { Saud. } \\
\text { Arabia }\end{array}$ & 15 & 18,811 & 0 & 2,531 & 0 & 144 \\
\hline Georgia & 15 & 497 & 0 & 156 & 0 & 6 \\
\hline Belarus & 9 & 11,289 & 0 & 1,740 & 0 & 75 \\
\hline Azerbaijan & 6 & 1,678 & 0 & 1,162 & 0 & 22 \\
\hline Turkey & 1 & 112,261 & 0 & 33,791 & 0 & 2,900 \\
\hline
\end{tabular}

Source: $[7,8]$

Coronavirus statistics by country as of April 27, 2020, 3,058,186 cases of the disease, 919,727 cases of convalescence and 211,147 cases of death were registered in the world. The coronavirus has infected 210 countries and territories. The worst situation is in the USA - 1,007,162 infected and 56,595 deaths. They are followed by: Italy - 199.414 and 26.977 respectively; Spain - 229,422 and 23,521; France - 165,842 165,842 and 23,293; Germany - 158,434 and 6,061, etc. (Table 2). The ability of countries to prevent and cope with disease outbreaks can be assessed by the Global Health Security Index (GHS) [9], which measures the effectiveness of health systems around the world. 2019 GHS Rankings Compiled For 195. At present, the states of the world continue to take measures to combat coronavirus infection and protect their populations: they have declared states of emergency and introduced quarantines, international flights have been postponed in accordance with the decision to close their borders, entire cities have been quarantined and the streets of densely populated cities have become empty. industrial enterprises are operating, where it is possible that people work from home, services are provided online, classes in schools and educational institutions have been transferred to distance learning, social events (scientific, cultural, sports) have been canceled, hygiene requirements have been strengthened, etc. Analysis of the World Tourism Organization (United Nations World Tourism Organization-UNWTO) shows that out of 217 destinations around the world: $45 \%$ have 
fully or partially closed their borders to tourists - "Passengers are not allowed to enter"; $30 \%$ fully or partially suspended international flights - "all flights are suspended"; $18 \%$ prohibit entry for passengers from certain countries of origin or passengers who have passed through certain destinations; $7 \%$ apply various measures such as quarantine or selfisolation for 14 days and visa measures [10]. The measures of protection introduced by the states have paralyzed various sectors of the economy, because of which both employers who lose profits and workers who are left without their usual income, who are without work, and who have no clear prospects for their future life, suffer. As of April 22, 2020, $81 \%$ of employers and $66 \%$ of individual workers live and work in countries affected by recommended or required job closures, with severe income and job implications [11]. According to the forecast of the International Monetary Fund as a result of the pandemic, the global economy will contract sharply - by $3 \%$ in 2020 , which is much worse than during the financial crisis of 2008-2009 [12]. This will be the largest economic crisis in the world economy, the symptoms of which are in reality: falling stock prices on world exchanges, rising gold prices, breaking international economic ties, falling prices for crude oil - it not only fell to its lowest level, but for the first time in history in general became negative, that is, it is less than \$ 0 per barrel. On April 20, 2020, the cost of American WTI crude oil for delivery in May dropped to minus $\$ 40.32$ per barrel. The situation is such that the consumer is even ready to pay extra, if only he took the product, and this is something extraordinary for the world economy [13].

The pandemic hit hard on the entire service market and especially on the tourism sector. International tourism was one of the first to feel the impact of the coronavirus pandemic, since it unites various types of economic activities and involves subjects of different nationalities. Travel and tourism are the locomotive of the world economy, a dynamically developing sphere of international trade and services. Coronavirus statistics by country as of April 27, 2020, 3,058,186 cases of the disease, 919,727 cases of convalescence and 211,147 cases of death were registered in the world. The coronavirus has infected 210 countries and territories. The worst situation is in the USA - 1,007,162 infected and 56,595 deaths. They are followed by: Italy - 199.414 and 26.977 respectively; Spain - 229,422 and 23,521; France - 165,842 165,842 and 23,293; Germany - 158,434 and 6,061, etc. (Table 2 ). The ability of countries to prevent and cope with disease outbreaks can be assessed by the Global Health Security Index (GHS) [4], which measures the effectiveness of health systems around the world. 2019 GHS Rankings Compiled For 195. At present, the states of the world continue to take measures to combat coronavirus infection and protect their populations: they have declared states of emergency and introduced quarantines, international flights have been postponed in accordance with the decision to close their borders, entire cities have been quarantined and the streets of densely populated cities have become empty. industrial enterprises are operating, where it is possible that people work from home, services are provided online, classes in schools and educational institutions have been transferred to distance learning, social events (scientific, cultural, sports) have been cancelled, hygiene requirements have been strengthened, etc. Analysis of the World Tourism Organization (United Nations World Tourism Organization-UNWTO) shows that out of 217 destinations around the world: $45 \%$ have fully or partially closed their borders to tourists - "Passengers are not allowed to enter"; $30 \%$ fully or partially suspended international flights - "all flights are suspended"; $18 \%$ prohibit entry for passengers from certain countries of origin or passengers who have passed through certain destinations; $7 \%$ apply various measures such as quarantine or self-isolation for 14 days and visa measures [14]. The measures of protection introduced by the states have paralyzed various sectors of the economy, because of which both employers who lose profits and workers who are left without their usual income, who are without work, and who have no clear prospects for their future life, suffer. As of April 22, 2020, 81\% of employers and 66\% of individual 
workers live and work in countries affected by recommended or required job closures, with severe income and job implications [15]. According to the forecast of the International Monetary Fund as a result of the pandemic, the global economy will contract sharply - by $3 \%$ in 2020, which is much worse than during the financial crisis of 2008-2009 [16]. This will be the largest economic crisis in the world economy, the symptoms of which are in reality: falling stock prices on world exchanges, rising gold prices, breaking international economic ties, falling prices for crude oil - it not only fell to its lowest level, but for the first time in history in general became negative, that is, it is less than $\$ 0$ per barrel. On April 20, 2020 , the cost of American WTI crude oil for delivery in May dropped to minus $\$ 40.32$ per barrel. The situation is such that the consumer is even ready to pay extra, if only he took the product, and this is something extraordinary for the world economy [17]. The pandemic hit hard on the entire service market and especially on the tourism sector. International tourism was one of the first to feel the impact of the coronavirus pandemic, since it unites various types of economic activities and involves subjects of different nationalities. Travel and tourism are the locomotive of the world economy, a dynamically developing sphere of international trade and services. Due to the quarantines and bans of many countries on the entry of tourists, hotels and airlines have to refund reservations and stop working. According to the World Travel \& Tourism Council (WTTC), the travel and tourism sector is facing a staggering 100.8 million job losses. Of these, almost 75 million are in the G20 countries. The WTTC analysis also shows a sharp increase in economic losses to the global economy - to $\$ 2.7$ trillion, up from $\$ 2.1$ trillion just a month ago. Asia (\$ -1.041 .0 billion) and America ( $\$-790.9$ billion suffer the most from the coronavirus pandemic [18]. Despite different calculations of the impact of the pandemic on international tourism, the real losses cannot be estimated, since it is not known when everything will end. Apparently, the borders won't open quickly. Due to the loss of jobs, the population's ability to pay decreases and, accordingly, the consumer behaviour of tourists changes. Under the conditions of the general quarantine and the calls to "stay at home", people are realizing that virtual reality is a reality and we must take advantage of it. Naturally, at present, nothing can replace real travel, but under the conditions of general quarantine, virtual tourism is the only way out of this situation. This powerful alternative for travel enthusiasts is based on realistic rendering of 3D multi-element space (3D). Gradually, it becomes possible to use four-dimensional measurement (4D), simulating sensory sensations. And then 5, 6, 7, $8 \mathrm{D}$ will follow, and apparently in the future they will grow into the most real everyday life. Virtual tourism has good prospects for development, because it has a number of attractive properties: you can travel at any convenient time without leaving your home, it is easy to satisfy the needs of a wide variety of interests, travel requires less money and time, if necessary, you can interrupt the trip and whenever you want continue it, you can easily switch from one direction (interest) to another, visit places of limited accessibility without much effort, there is no danger of infection, etc. Currently, you can make virtual trips to different countries and cities on Google maps, art lovers from virtual tours can get acquainted with the works of many famous masters of painting from the museums of the Louvre (Paris, France), the Hermitage (St. Petersburg, Russia), the Metropolitan (New York, USA), Van Gogh (Amsterdam, the Netherlands), Orsay ( Paris, France), Uffizzi (Florence, Italy) and many others, you can virtually climb the Eiffel tower, wander among the rocks in the Grand Canyon, admire the starry sky above the summit of Everest, inspect the Kremlin Armory, etc., you can listen to online broadcasts from the Vienna Opera, Milan's La Scala Opera, etc., attend performances of various theatres around the world etc [19]. In conclusion, it should be noted that the COVID-19 pandemic is a serious challenge to humanity. It provokes the destruction of global ties, the collapse of the modern world order and has devastating economic consequences. However, under its influence, a new level of human development appears, based on new information technologies and media. People learn to 
survive in self-isolation and live in virtual space. This survival is facilitated to a certain extent by virtual tourism, which has great prospects for development.

\section{References}

1. Yan, G., Lee, CK., Lam, LTM., Yan, B., Chua, YX., Lim, AYN., Phang, KF., Sen, K. G., Teng, H., Ngai, CH., Lin, L., Foo, RM., Pada, S., Ng, LC., Tambyah, PA. (2020). Covert COVID-19 and false-positive dengue serology in Singapore. Lancet Infectious Diseases, 20(5), 536-536.

2. Rodriguez-Morales, AJ., Gallego, V., Escalera-Antezana, JP., Mendez, CA., Zambrano, LI., Franco-Paredes, C., Suarez, JA., Rodriquez-Ensico, HD., BalbinRamon, GJ., Savio-Larriera, E., Risquez, A., Cimerman, S. (2020). COVID-19 in Latin America: the implications of the first confirmed case in Brazil. Travel Medicine and Infectious Disease, 35, 101613.

3. Li, RY., Pei, S., Chen, B., Song, YM., Zhang, T., Yang, W., Shaman, J. (2020). Substantial undocumented infection facilitates the rapid dissemination of novel coronavirus (SARS-CoV2). Science, 368(6490), 489-+

4. Rodriguez-Morales, AJ., Gallego, V., Escalera-Antezana, JP., Mendez, CA., Zambrano, LI., Franco-Paredes, C., Suarez, JA., Rodriquez-Ensico, HD., BalbinRamon, GJ., Savio-Larriera, E., Risquez, A., Cimerman, S. (2020). COVID-19 in Latin America: the implications of the first confirmed case in Brazil. Travel Medicine and Infectious Disease, 35, 101613.

5. Li, RY., Pei, S., Chen, B., Song, YM., Zhang, T., Yang, W., Shaman, J. (2020). Substantial undocumented infection facilitates the rapid dissemination of novel coronavirus (SARS-CoV2). Science, 368(6490), 489-+

6. Coronavirus statistics in the world today (2020, March 11). Retrieved from: https: //xn--80aesfpfapfkv.xn--80asehdb/stat/8-statistika-koronavirusa-na-segodnja-11 marta .html

7. Covid-19 coronavirus pandemic (2020, April 27). Retrieved from: https://www.worldometers.info/coronavirus/

8. Global Health Security Index (2019, October). Building Collective Action and Accountability. Retrieved from: https://www.ghsindex.org/wpcontent/uploads/2019/10/2019-Global-Health-Security-Index.pdf

9. World leaders join forces to ensure universal and universal access to new vaccines, diagnostics and treatments to combat COVID-19 (2020, April 24). Retrieved from: https://www.who.int/ru/news-room/detail/24-04-2020-global-leaders-unite-to-ensureeveryone-everywhere-can-access-new-vaccines-tests-and-treatments-for-covid-19

10. UNWTO (2020, April 28). 100\% of global destinations now have covid-19 travel restrictions, unwto reports. Retrieved from: https://www.unwto.org/news/covid-19travel-restrictions

11. International Labor Organization. ILO Monitor: COVID-19 and the world of work. Third edition (2020, April 29). Retrieved from: https://www.ilo.org/wcmsp5/groups/public/@dgreports/@dcomm/documents/briefingn ote/wcms_743146.pdf

12. Lorenz, C., Azevedo, TS., Chiaravalloti-Neto, F. (2020). COVID-19 and dengue fever: A dangerous combination for the health system in Brazil. Travel Medicine and Infectious Disease, 35, 101659. 
13. Chen, NS., Zhou, M., Dong, X., Qu, JM., Gong, FY., Han, Y., Qiu, Y., Wang, JL., Liu, Y., Wei, Y., Xia, JA., Yu, T., Zhang, XX., Zhang, L. (2020). Epidemiological and clinical characteristics of 99 cases of 2019 novel coronavirus pneumonia in Wuhan, China: a descriptive study. Lancet, 395(10223), 507-513.

14. Fung, M. (2020, April 26): Planning overseas college education amid pandemic. Retrieved from: https://www.straitstimes.com/business/invest/planning-overseascollege-education-amid-pandemic. https://hightech.fm/2020/03/18/covid-19-pandemia

15. Saavedra J. (2020, March 30). Educational challenges and opportunities of the Coronavirus (COVID-19) pandemic. Retrieved from: https://blogs.worldbank.org/ education/educational-challenges-and-opportunities-covid-19-pandemic

16. IMF. World Economic Outlook (2020, April). The Great Lockdown. Retrieved from: https://www.imf.org/en/publications/weo

17. Covid-19 coronavirus pandemic (2020, May 05). Retrieved from: https://www.worldometers.info/coronavirus/

18. Mensi, W., Sensoy, A., Vo, XV., Kang, SH. (2020). Impact of COVID-19 outbreak on asymmetric multifractality of gold and oil prices. Resources Policy, 69, 101829.

19. Huang, JK. (2020). Impacts of COVID-19 on agriculture and rural poverty in China. Journal of Integrative Agriculture, 19(12), 2849-2853.

20. Ferrannini, A., Barbieri, E., Biggeri, M., di Tommaso, M. R. (2021). Industrial policy for sustainable human development in the post-Covid19 era. World Development, 137, 105215.

21. Gopalan, H. S., Misra, A. (2020). COVID-19 pandemic and challenges for socioeconomic issues, healthcare and National Health Programs in India. Diabetes \& Metabolic Syndrome: Clinical Research \& Reviews, 14(5), 757-759.

22. Watkins, J., Maruthappu, M. (2020). Public health and economic responses to COVID19: finding the tipping point. Public Health, In Press, Journal Pre-proof. 